Reprod. Nutr. Dévelop., 1986, 26 (1 A), 113-126.

\title{
Post-parturition and late lactation urine : long-term effects of exposure on mouse activity and sniffing behaviour
}

\author{
J. J. COWLEY, R. K. PEWTRESS
}

School of Natural Sciences, The Hatfield Polytechnic, College Lane, Hatfield, Herts. AL $109 A B$, U.K.

Summary. From the time of separation from their mothers infant mice were exposed for 10 consecutive days to urine from post-parturitional and late-lactational donor mice. They were then tested when adult on activity and sniffing behaviour.

The sample of mice exposed to urine from late-lactational donors was associated with reduced activity when compared with mice exposed to post-parturitional urine and a water control sample. The long term effects of the urine on behaviour were also apparent in positional preferences in an open arena as judged by frequency of entry, and to a lesser extent, the time spent in the left and right hand segments. Mice exposed to late-lactational urine sniffed less than the other treatment samples though preferences for sniffing the urine that they had been exposed to in infancy were less marked. The urine did not accelerate puberty, but mice in the control sample had more vaginal dioestrous smears and fewer smears with a predominance of epithelial cells.

\section{Introduction.}

Exposing infant female mice to the presence of adult female conspecifics slows the rate of sexual maturation (Vandenbergh, 1967, 1969; Fullerton and Cowley, 1971) and the substance(s) responsible for the delay are contained in the urine (Cowley and Wise, 1970 ; Drickamer, 1977 ; Colby and Vandenbergh, 1974). The picture is, however, complicated and a change in the composition of the urine, consequent upon a change in the reproductive state of the female, may have either a retarding or an accelerating effect on sexual development. The urine of pregnant and lactating mice accelerates the onset of the first oestrous while urine from virgin female mice may delay the onset of puberty (Drickamer and Hoover, 1979 ; Cowley and Wise, 1972). While sexual maturation and changes in the regularity of oestrous cycle have formed a focus of interest the effects of exposure on the behaviour of mice has received little attention. An increase in open field activity following exposure, in infancy, to adult male conspecifics contrasted with the effects of exposing infant mice to adult females (Fullerton and Cowley, 1971). In the latter the latency time, assessed by the time delay in moving away from the segment of the field where the mouse was first introduced, was enhanced. In rats the lordosis reflex is not modified by pheromonal secretions from pregnant and 
lactating animals though the odours from lactating mothers lengthen the oestrous cycle and those from pregnant mothers shorten it (McClintock, 1983). Similarly, rats housed in activity wheels respond to the odour of urine from lactating and pregnant animals with changes in the length of the oestrous cycle and wheel running activity (Cowley and Wise, 1970).

Here we examine the effects of exposure to the urine of lactating mice, early in life, on the activity of the mice when adult. The effects of the urine collected within 24 hours of giving birth, that is during the post-parturition oestrous, is contrasted with the effects on the infants of urine collected towards the end of lactation. The effects of the urine on sniffing behaviour, the acceleration of puberty, and the vaginal components of the oestrous cycle are also examined.

\section{Materials and methods.}

Animals. - A sample of TO strain (Theiler Original) pregnant mice were purchased from a commercial breeder one week prior to parturition. Litters born on the same day were mixed together and the females allocated to the mothers on a random basis. All male babies were discarded. The mothers and infants (4-6 per litter) were housed in plastic breeding cages $(30 \times 13 \times 11.5 \mathrm{cms}$ high $)$ in a room away from male members of the colony. Food and water were available at all times and three tungsten lights $(3 \times 60$ watt $)$ provided an artificial $12: 12$ hour light/dark cycle (lights on at $6.00 \mathrm{am}$ ). Temperatures were maintained at $21^{\circ} \mathrm{C}$. The mice were not disturbed except for cage cleaning and colony maintenance until separated from the mothers at 21 days of age. The litters were allocated on a random basis to one of three treatments.

One recipient sample was exposed to urine collected from donor mothers (see below) $24 \mathrm{hrs}$ after giving birth (post parturitional sample) while the second was exposed to urine collected from donors during the last week of lactation (18 days post parturition referred to as the late lactational). A third sample was treated with distilled water.

Lactating mothers of the same age and strain provided the donor urine. Details of the collecting, storing and application of the urine have been described elsewhere (Cowley and Wise, 1972). The urine from 5-6 mothers was mixed together and diluted with distilled water in a ratio of 5 parts of water to 1 part of urine and applied, with a fine artist's paintbrush, once daily to the dorsal nasal surface when the mice were 22-32 days of age.

The 31 recipients were exposed 19 in each of the two urine and 13 in the water control sample), from the time they were separated from their mothers, for ten days and were examined daily for vaginal introitus. Vaginal smears were taken once daily for 10 days from vaginal opening. The mice were weighed at weaning, immediately after treatment, and when 80 days of age. They were tested for spontaneous motor activity (see below) both in the presence of urine from the lactating mothers and in a control condition where water only was present.

Testing procedures. - Automatic recording of the activity of the mice was achieved through a scanner unit (Panlab Actisystem, Ormed Ltd, Welwyn Garden 
City, U.K.). The system allows for the simultaneous recording of a number of levels of sensitivity and as such may differentiate between kinds of movement. The mice were tested individually, in a perspex arena $(29 \times 23.5 \times 20 \mathrm{cms}$ high) mounted on the scanner unit, for two minutes on four consecutive days when 42 days of age. The two selected sensitivity levels in the present experiment were 4 and 7. The latter primarily records locomotion about the field while the former was activited by such movements as the mouse lowering its body, from an upright position against the wall of the arena, on to the floor, though rapid startle movements, often with the back arched, would also be registered. The amount of time spent on the left and right hand side of the arena was also recorded. For this purpose two parallel lines were drawn on the base of the arena and some $8 \mathrm{cms}$ from the two shorter sides. An independent recording system enabled the frequency with which the mice entered these segments to be recorded and provided a printout of the time spent in them. Mounted centrally $13 \mathrm{cms}$ above the floor of the arena on the two smaller sides were two disposable plastic beakers $(4.5 \times 3.5 \mathrm{cms})$. The beakers were mounted diametrically opposite each other, screwed to the wall of the arena, and their open ends covered with a fine wire mesh. A dental swab with urine from lactating mice, or with water as a control, was placed in the beakers, well out of reach of the mice, though the odours could be detected through the mesh by the animals. Separate beakers were used for the different treatments and care was taken to ensure there was no contamination between treatments. To reduce positional preferences the arena was rotated once each day through $180^{\circ}$.

On Day 1 and 4 of testing both beakers had cotton wool swabs with only distilled water on them. On Day 2 early postparturitional urine was placed in one of the beakers and the other had cotton wool with late lactational urine. On the third day the position of the early and late lactational urine was reversed through the rotation of the arena (see above). The frequency with which the mice sniffed at the beakers was recorded and the number of stools passed on each of the trials noted. The dilution of the urine was the same as that used for exposing the mice and $0.1 \mathrm{ml}$ of the urine, or of distilled water, was placed on the cotton wool buds.

At 80 days of age the uterus, left ovary and left adrenal gland of the recipient mice were removed and weighed.

Statistical analysis (One-way Analysis of Variance and Duncan's New Multiple Range Test) was carried out with use of SPSS (2nd Edition) on a DEC 1091 Computer.

\section{Result.}

1. Activity.

(i) Panlab sensitivity ' 7 '. - There were significant differences between treatments when test trials were summed over the four testing days ( $p=<$ 0.04). The mice exposed to the late pregnancy urine were less active (fig. 1) than those exposed to the control $(p=<0.05)$ and post-lactanional treatments 


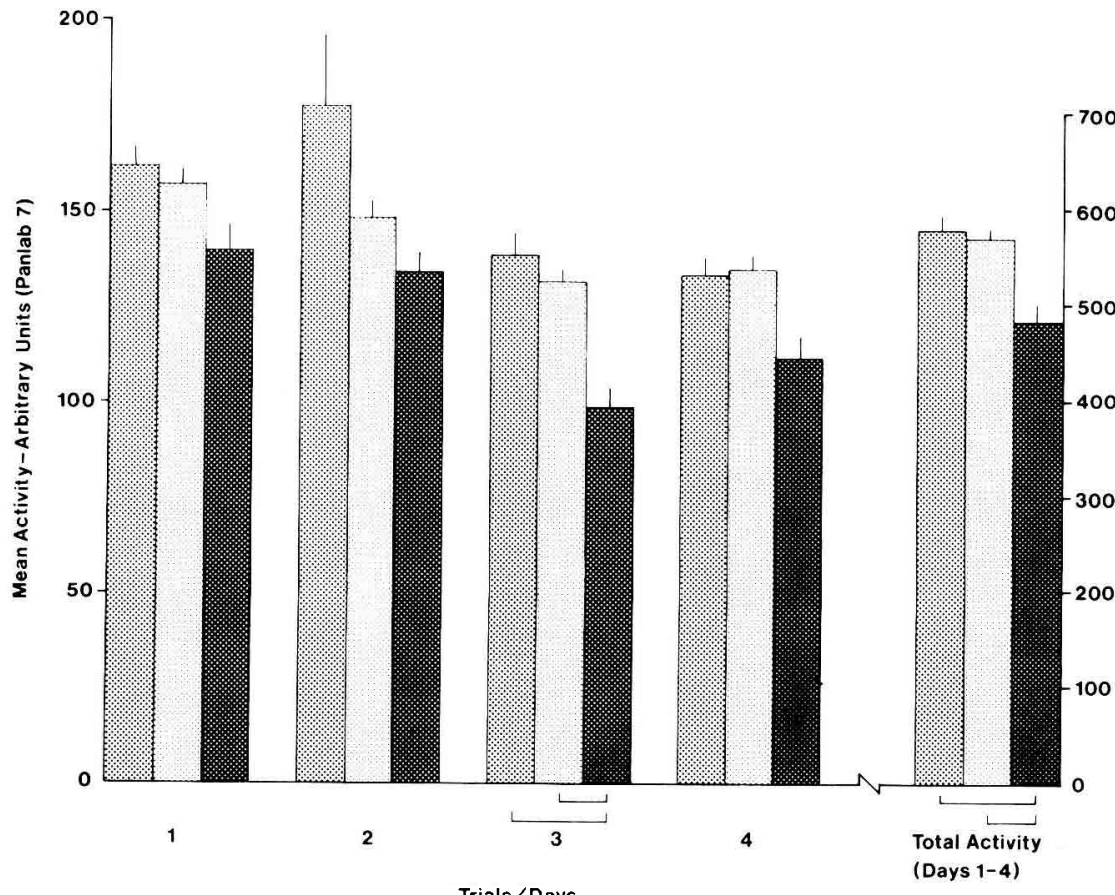

FIG. 1 .

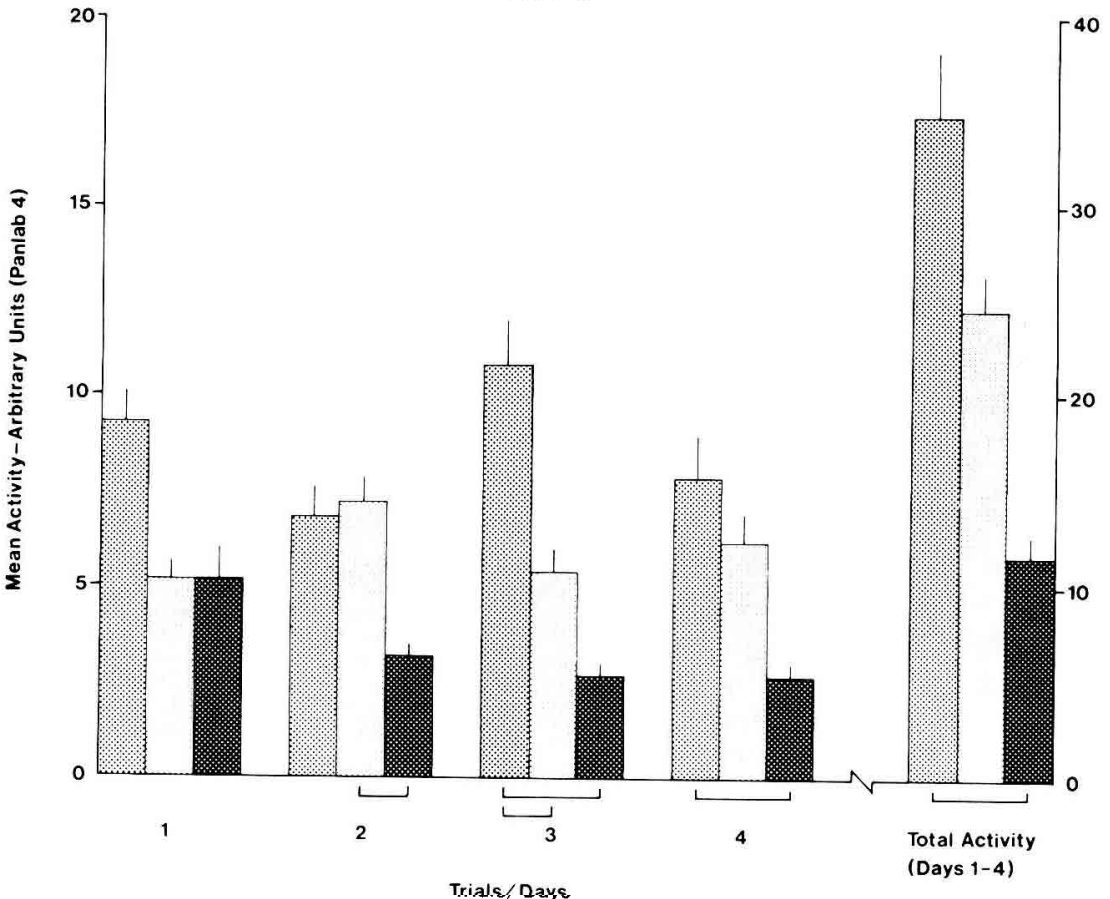

FIG. 2. 
( $p=<0.01)$. On the third trial mice exposed to late-lactational urine were also less active than the water and post-parturitional samples ( $p=<0.05$ in both instances) but there were no other significant differences on the other individual test trials.

(ii) Panlab sensitivity '4'. - There were again marked differences between the treatments in the activity of the mice when the four test trials were summed $(p=<0.01)$. The control sample accupied a position midway between the postparturitional mice which scored high and those exposed to the urine of latelactating mothers which scored low on activity (fig. 2). The differences in overall activity between the post- and late-lactational were significant ( $p=<0.05$ ), but the differences between the control and the other treatment groups did not reach an acceptable level of statistical significance. The post-lactational mice had the highest levels of activity in three out of the four individual trials but only on the third trial, were the differences between treatments markedly significant ( $p=<0.01$ ). The post-lactational mice being more active than both the water control and late-lactating urine samples ( $p=<0.05$ in both cases). In the second trial the late-lactational mice scored lower than the control sample $(p=<0.05)$ and in the fourth trial there was a significant difference between the two urine treated samples $(p=<0.05$ ) with the post-lactational mice more active.

\section{Entrance to left and right segments.}

Two further indices of activity were used, namely the frequency with which the mice entered the left and right segments of the floor of the arena. The overall frequency of entry into the left hand segments, when trials were combined, was significant ( $p=<0.02$ ) and the treatment groups showed a similar ordering in relation to total entrances into the right hand segment though the differences did not reach an acceptable level of significance $(p=<0.10)$. In relation to left hand entries (fig. 3) it was the control and post-parturitional mice that entered the segment (trials combined) more often than the late-lactational mice (in both cases $\mathrm{p}=<0.05)$. There was a similar significant difference between samples on trial 2 ( $p=<0.01$ ) with the control and post-parturitional samples entering the lefthand segment more frequently than the late-lactational mice $(p=<0.05)$. The late-lactational sample also made fewer entries into the right-hand segment (fig. 4) than the post-parturitional treated sample $(p=<0.05)$ and the same differences were apparent on the third trial $(p=<0.05)$. There were no other statistically significant differences between the treatment groups.

FIG. 1 \& 2. - Mean activity scores as a function of days for levels of sensitivity '4' and '7'. The dark columns represent females exposed to late-lactational urine and the pale columns represent the scores of the mice exposed to water. The columns intermediate in tone show the scores of mice exposed to post-lactational urine. The mice were exposed to the treatments for 10 days from 21 days of age and tested when adult. Treatments connected with the horizontal line-brackets differ significantly from each other. 


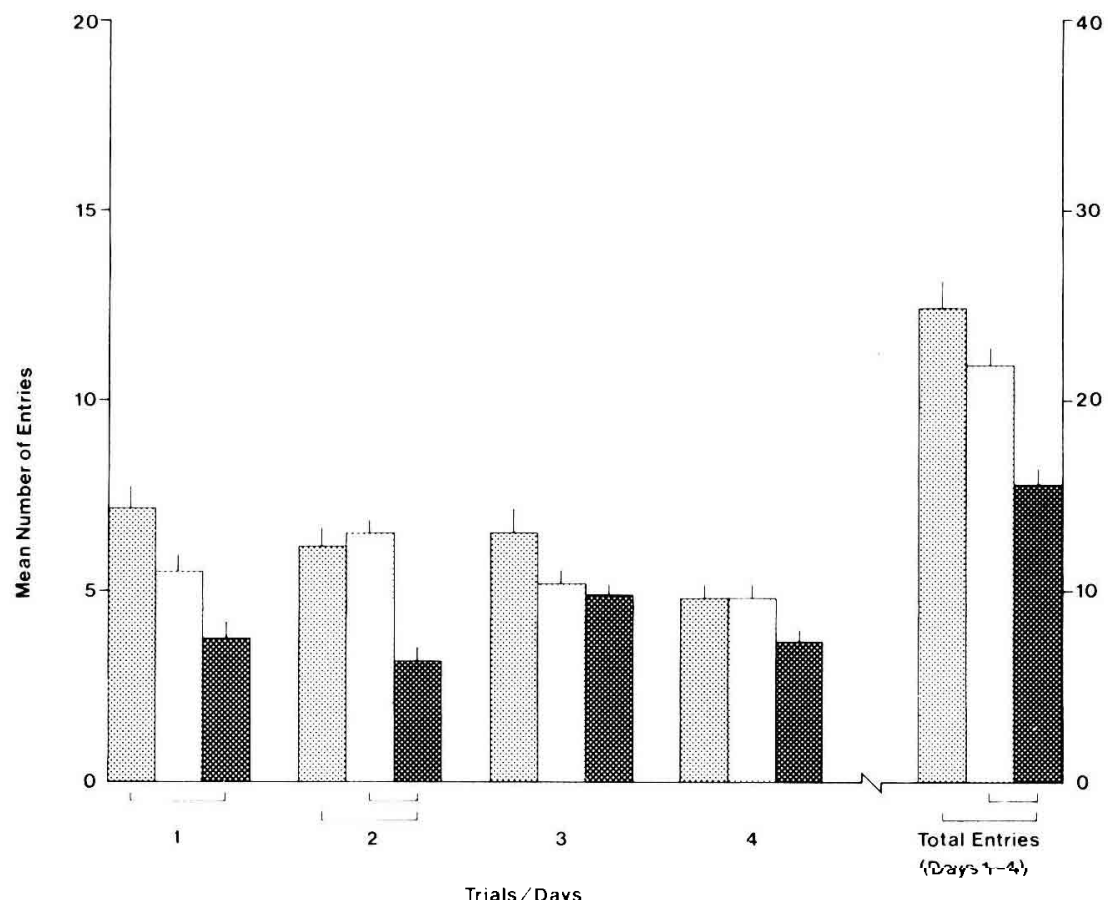

FIG. 3 .

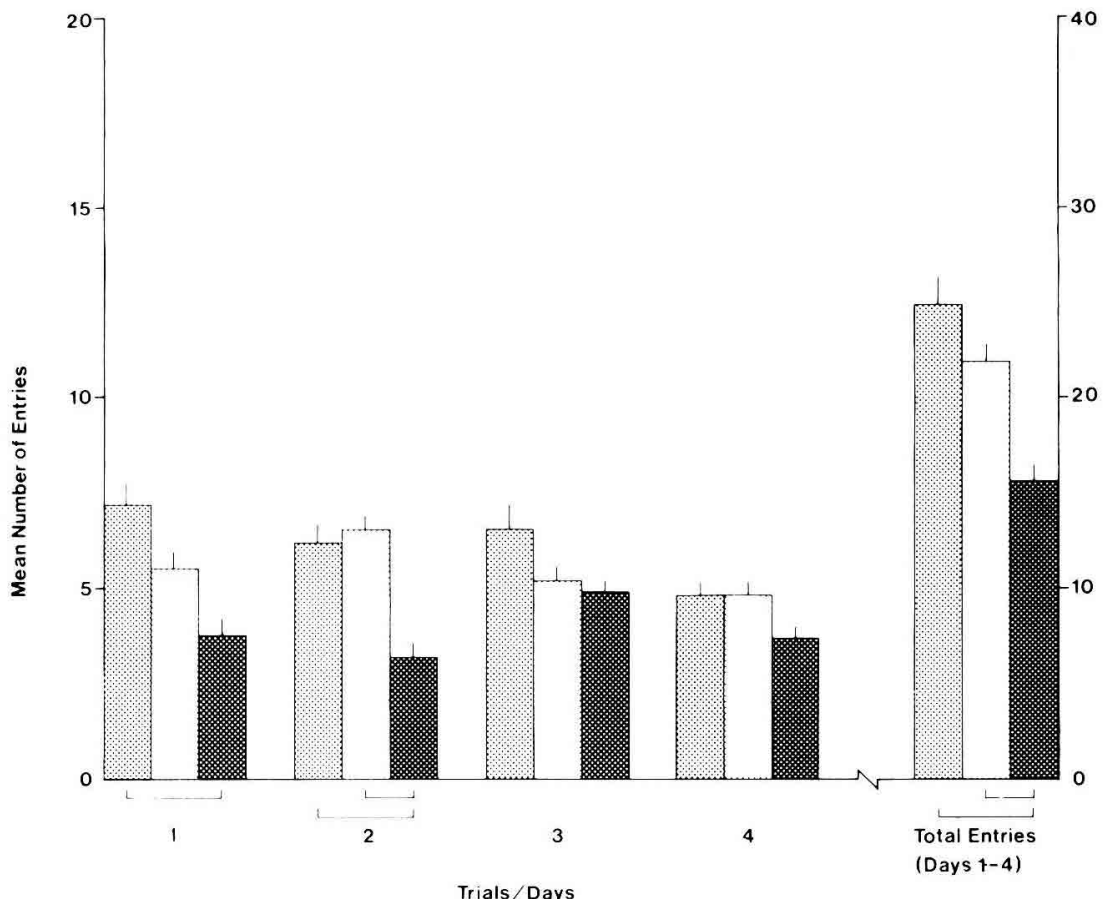

FIG. 4. 


\section{Time spent in the left and right segments.}

There were no differences in the overall amount of time spent by the treatment samples in the left-hand side of the arena (all trials combined). There was, however, an overall difference between treatments on trial 2 ( $p=<0.01$ ) where late-lactational mice spent less time on the side of the arena where the post-parturitional urine was present than either the post parturitional or water control samples (in both cases $p=<0.05$ ). In the third trial, when the position of the post-parturitional urine was reversed, there was again a significant difference between treatments $(p=<0.03)$, the late-lactational sample spending more time on the side with the late-lactational urine than the control mice $(\mathrm{p}=<0.05)$.

When the overall time spent in the right-hand section of the arena is examined (fig. 6) there is a marginal difference between treatments ( $p=<0.10)$. In the first trial, when both beakers contain water, the differences between treatments are significant $(p=<0.04)$ with the late-lactational mice spending more time in the right-hand segment than those exposed to the postparturitional urine $(p=<0.05)$ and continue to spend more time in this section on the second trial with post-lactational urine present loverall difference between treatments, $p=<0.02$ ). The amount of time spent in the right-hand segment in trial 2 is greater than that spent by the control and post-parturitional mice in this segment ( $p=<0.05$ in both cases).

\section{Sniffing behaviour and frequency of defecation.}

There are marked differences between treatments in the total number of sniffs over the four days of testing $(p=<0.004)$. Mice treated with the latelactational urine show a low level of sniffing compared with the post-parturitional and control mice ( $p=<0.05$ in both cases). The same striking difference between treatments (fig. 7) occurs on the second and third trial ( $p=<0.01$ ) and the pattern of results is also apparent in trial 4 though ( $p=<0.03$ ) on this trial the mean difference between the late-lactational and water control group is not statistically significant. The treatment groups on the first day of testing, when only water is present in the beakers, show the same characteristic rank ordering observed on the subsequent trials but mean differences between treatments were not statistically significant. Further, there was no evidence that the treatment groups showed a left or right-hand preference in sniffing the beakers.

FIG. 3 \& 4. - The mean entry scores to the left hand side (fig. 3) and right hand side (fig. 4) of the arena for the four consecutive days of testing are shown. The mice exposed to late-lactational urine (dark columns), the water control sample (light stippled columns) and those exposed to the post-lactational urine (columns intermediate in tonel are shown. The horizontal line-brackets show treatments where the mean scores differ significantly. 


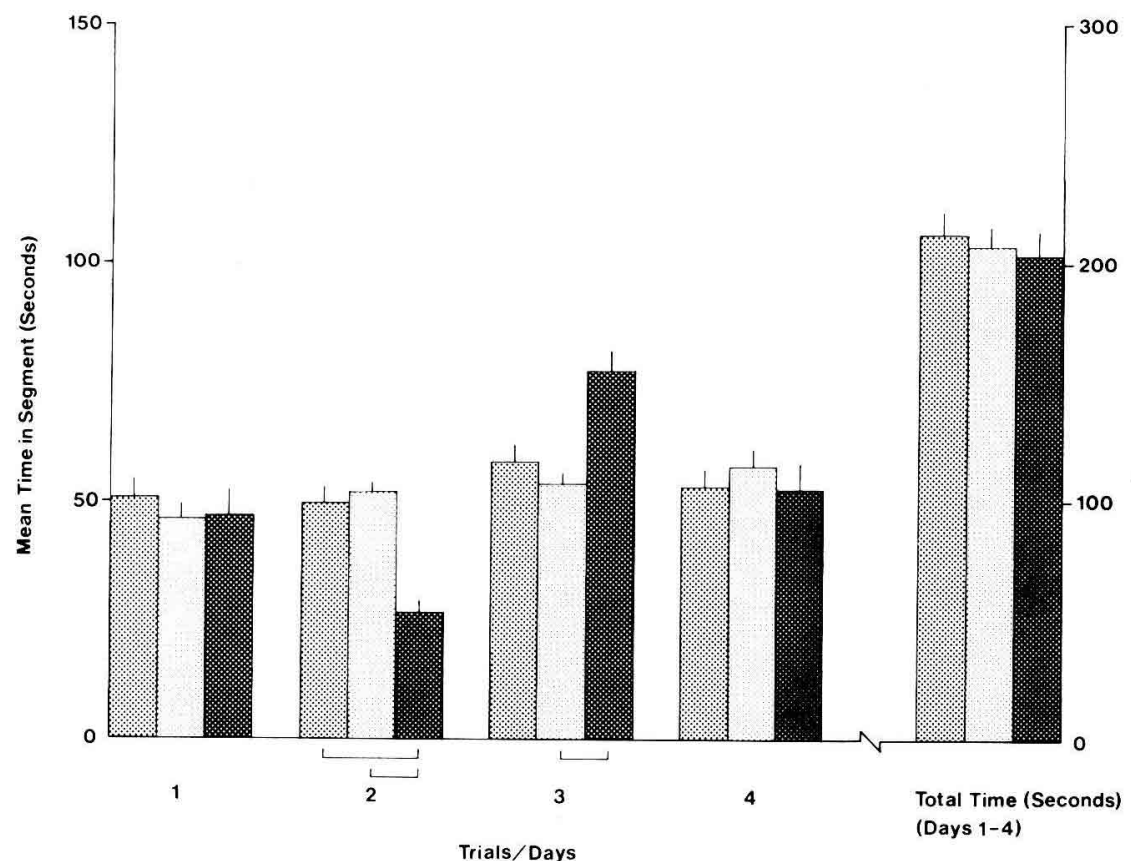

FIG. 5.

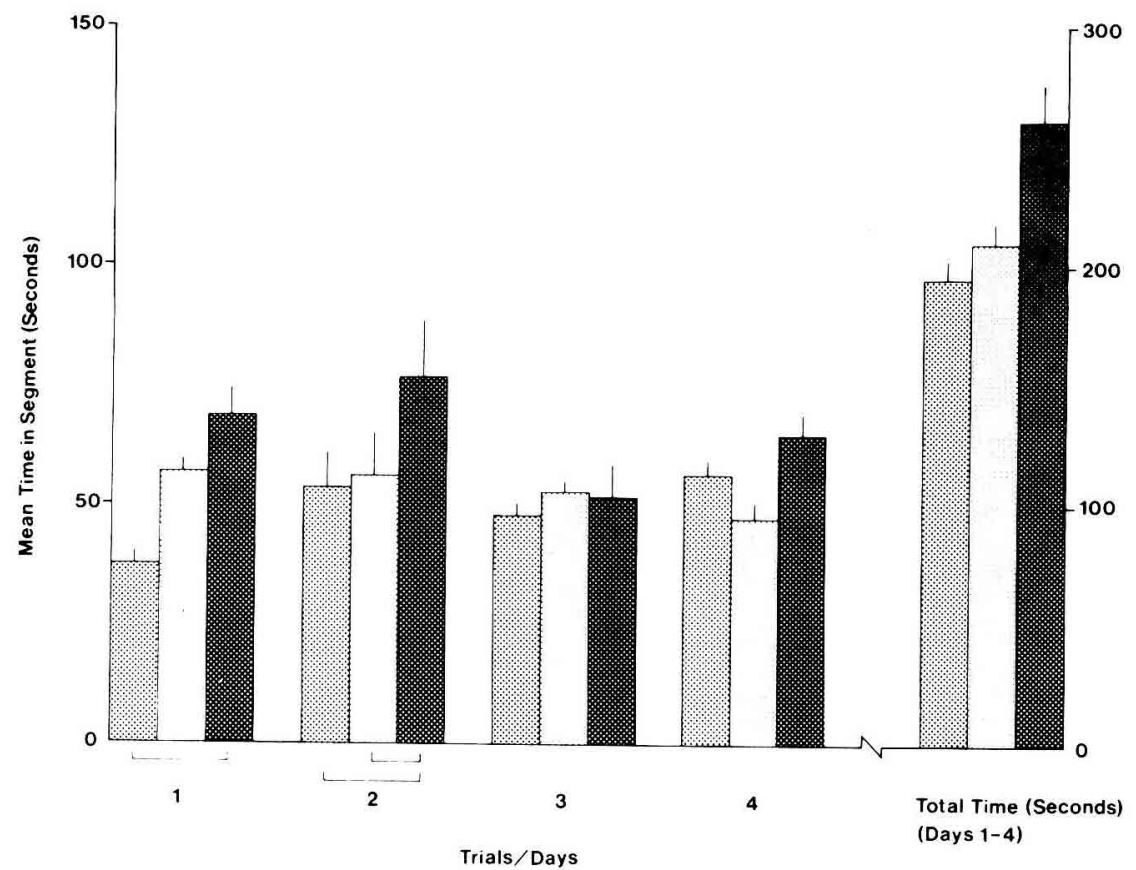

FIG. 6. 


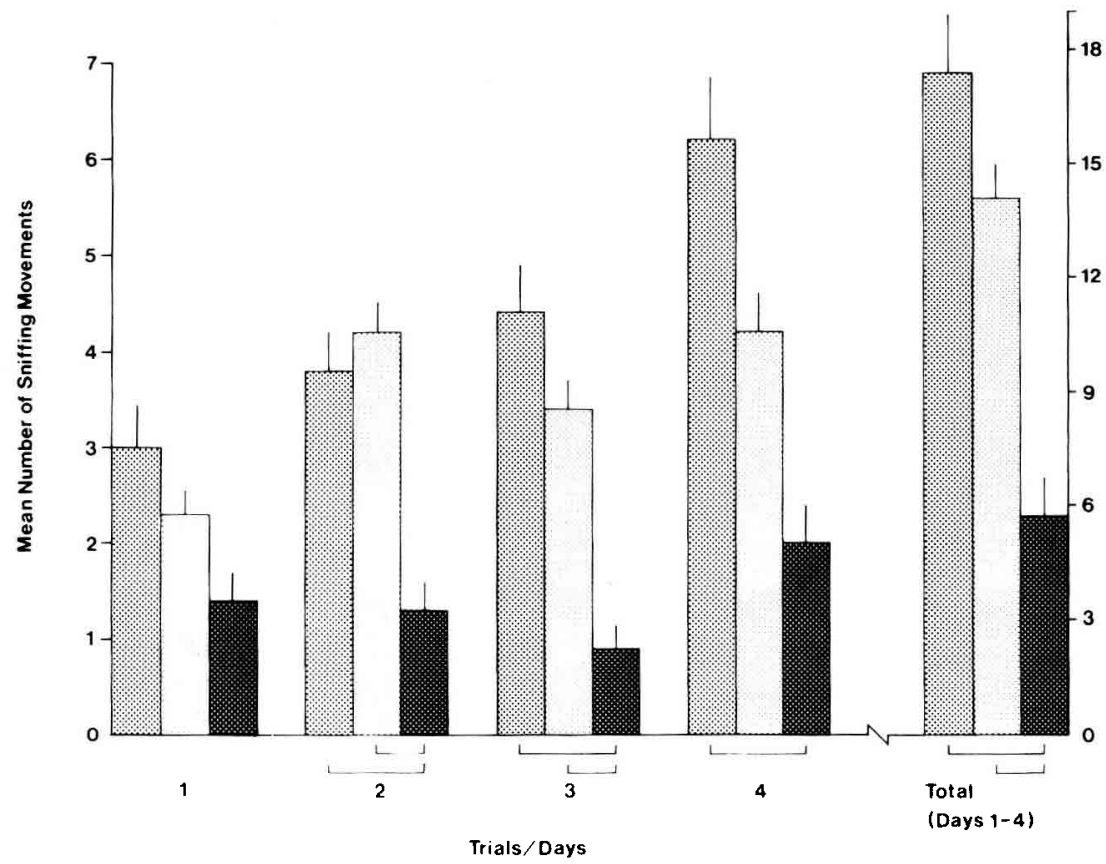

FIG. 7. - The mean number of sniffing movements recorded over the four consecutive days of testing are shown for the mice exposed, early in life, to the urine of late-lactational (dark columns), postparturitional donors (columns intermediate in tone) and a water exposed control sample (light stippled columns). The horizontal line-brackets show treatments which differ significantly.

The number of vaginal smears classified as pro-oestrous and oestrus was much the same between treatments and there were also no significant differences between treatments in the number of metoestrous smears. The mean number of smears with a predominance of epithelial cells was different between treatments $(p=<0.02)$ and this was accounted for by the control having a lower mean number of these sequence of smears than the post-lactational sample $(p=<0.05)$. The mean number of dioestrous smears also differed between treatments $(p=<0.02)$ with the water control having a greater number of smears in this category than the post-lactational sample $(p=<0.05)$. The mice exposed to the late-lactational urine occupied a position between the water and post-lactational samples. There was no significant difference between these treatments.

FIG. 5 \& 6. - The mean time (seconds) spent in the left (fig. 5) and right hand segments (fig. 6) of the arena as a function of days of testing are shown. The mice exposed early in life to the urine of late-lactational donors (dark columns) are contrasted with those exposed to the urine from post parturitional mice (columns intermediate in tone) and a water exposed control sample (light stippled columns). The horizontal line-brackets show treatments wehere the mean scores differ significantly. 
The control mice sniffed the late-lactational urine almost as frequently as they did the post-parturitional urine $(48: 51)$ but both the mice exposed to the post-parturitional urine $(31: 43)$ and those exposed to the late-lactional urine (6: 14) preferred to sniff the post-parturitional urine. In three out of the four trials, the mice exposed to the post-paturitional urine sniffed more often than did the control sample and their overall rate of sniffing was greater than that of the control mice but not significantly so.

There were no differences between treatments in the number of stools deposited in the open arena and the mean numbers for the four trials combined were similar for the different treatments.

\section{Sexual maturation and vaginal cell components.}

The mean age of vaginal introitus did not differ significantly and there was also no evidence that the onset of first oestrous was accelerated in any of the treatment groups.

\section{Ovary, uterus and adrenal weights.}

The uterus, the left ovary and left adrenal gland were removed and weighed at 60 days of age and the weights of these organs expressed as a percentage of the body weight of the mice. There were no significant differences between treatments in body weight or in the weight of these tissues.

\section{Discussion.}

The results show that urine collected from late-lactating mothers and applied daily to the nasal region of infant mice for 10 days after weaning has a marked effect on their subsequent behaviour when adult. The mice show a low level of activity in an arena compared with control mice. The differences in the levels of activity of the mice exposed to late-lactational and post-parturitional urine were even more marked and suggests that urine from these two different stages of lactation affect behaviour in diametrically opposite directions. The activity scores show both consistency over trials and on the two levels of test sensitivity though the results are more marked when fast running movements and the lowering of the body against the floor of the arena are recorded. Confirmation of the activity differences as between treatments was seen in the frequency with which the mice entered the segments adjacent to the sides of the arena. The mice treated with late-lactational urine made fewer entries and the pattern of results was similar for both the left and right segments.

The response to novelty in mice is largely determined by olfactory stimulation (Misslin and Ropartz, 1981) and the results show that the exposure to the urine of the lactating donors has also led to a lasting alteration in sniffing behaviour as 
between treatments. The mice exposed to late-lactational urine early in life sniffed less than the control and the mice exposed to the post-parturitional urine. A functional explanation of the advantages of such polarity may lie in the developmental history of the animals. Infant mice weaned at 35 days of age were subsequently found, when adult, to be less active in an Open Field test than mice weaned at 21 days of age. The differences in Open Field activity were confined to the first trial but similar results were obtained with Wistar rats where the comparison was limited to an early and late weaned sample (Cowley et al., 1969). The present results suggest that the reduced activity in these early studies may have been due to factors present in the mothers' urine. Qualitative differences in the composition of the urine may also promote differences in behaviour. Urine from highly active lactating mice raises activity levels when applied to the nasal region during the first 21 days of life and the finding contrasted with that of infant mice that had been treated with the urine of inactive lactating mothers and subsequently found when adult, to be less active (Cowley and Smale, 1986). The recipients were exposed to the urine at a time when they were sucking from their mothers and the results may have been confounded by an interaction between the urine from the mothers and that from the active and inactive donors. In the present study, however, the mice were exposed to the urine after separation from the mothers and consequently the interaction effects, between infant and mother, are neglegible though we cannot preclude the possibility that the donor urine may have exerted some additive trace effect with that of the mothers.

The low level of sniffing in the mice exposed to the late-lactational urine is the obverse of that associated with exposure in infancy to the urine of adult male mice which is associated with heightened activity and an increase in sniffing behaviour (Harvey and Cowley, 1984). The increase in sniffing behaviour following exposure to male urine is similar to that following exposure to postlactational urine and suggests that the post-lactational sample has been masculinised in this regard. The male mice were exposed to the urine at a younger age (first three weeks of life) and the design of the experiment was such that the mice did not have direct access to the urine. The volatile secretions thus seem able to act from a distance and implicate the olfactory rather than the vomeronasal system though in more naturel situations, and as in the present investigation, both may be utilised.

Female mice exposed to male urine during the first 21 days of life also show a change in the number and distribution of mitral cells in the dorsolateral and dosomedial regions of the olfactory bulbs (Harvey and Cowley, 1984). The effects of exposing infant mice to adult female urine on the histology of the cells of the bulbs is unknown but some appreciation of the functional significance of the altered cells may be anticipated. The change in $\mathrm{LH}-\mathrm{RH}$ and in norepinephrine that occur in localised regions of the olfactory bulbs in the female vole and in the dorsal olfactory bulbs of male mice following brief exposure to an intact male or an ovarectimised female suggest that brief social interactions are in themselves adequate conditions to ensure transmitter modifications within the nervous system (Dluzen et al., 1981 ; Dluzen and Ramirez, 1983). The alteration of gross activity and basic reflex patterns like sniffing and orientation to the olfactory 
stimulus, as seen in the present study, may also extend to more complex behavioural changes as seen in the Bruce effect (Bruce, 1959) where memory has been implicated (see also Keverne and de la Riva, 1982).

Urine from lactating mice has been reported to have an accelarating effect on the onset of puberty in female mice (Drickamer and Hoover, 1979) and the duration of ovulation and oestrus is increased within a cycle (Drickamer and Hoover, 1979) though the length of the cycle is not changed. In the present study the onset of oestrous was not advanced significantly but the exposure to postparturitional urine was associated with an increase in the sequence of vaginal smears and epithelial cells and a corresponding decrease in the number of dioestrous smears when compared with the control samples. The changes may reflect the high oestrogen levels associated with post-partum oestrus (Bingel and Schwartz, 1969a, b) but the accompanying hormonal changes associated with the establishment of lactation confounds the picture and identification of the particular volatile components or hormones responsible for the underlying changes in vaginal cytology must remain open.

The immediate advantages accrued by the action of the late-lactational urine in lowering levels of activity and responsiveness are that it may promote infants remaining in the nest (Csermely, 1981) and, as a consequence, the obtaining of resources (warmth, territory, food) from the mother and avoidance of preditors at a time when the mice may otherwise be prone to be taken. A self-regulatory system may be operative. Mothers who spend much time with their litters may delay the age at which the young move away from the nest and mothers who are present for a shorter period of time because of limited food supplies or large numbers of competing mouths to feed would, through the limited presence of their secretions in the nest, evoke an early spontaneous leaving of the nest. That a controlling system is present is suggested by the tendency of mothers with large litters (and hence heavier demands on the milk supply) to spend less time with their young than mothers nursing small litters (Foote, 1974), though the rate of growth will differ as between the two and the advantages accrued through rapid growth (small litters) may be further enhanced by the additional presence of the mother's pheromonal secretions.

Reçu en juillet 1985.

Accepté en novembre 1985.

Résumé. Exposition de souriceaux femelles à l'urine prélevée chez des souris après la mise bas ou en fin de lactation. Effets à long terme sur l'activité et le comportement de reniflement.

Dès leur naissance, les souris ont été séparées de leur mère. et, pendant 10 jours consécutifs, ont été exposées à l'urine recueillie chez des donneuses soit $24 \mathrm{~h}$ après la parturition, soit en fin de lactation. Une fois adultes, ces souris ont été soumises à des tests sur leur activité et leur manière de renifler.

L'échantillon de souris exposées à l'urine de donneuses en fin de lactation a fait montre d'une activité réduite en comparaison de celle observée chez les animaux exposés à l'urine de donneuses après la parturition, comme chez ceux (" contrôle ") exposés à de l'eau. Les effets à long-terme de l'urine sur le comportement ont été également apparents dans les choix de position des souris dans un champ d'activité ouvert, à en juger par la 
fréquence des entrées, et, dans une moindre mesure, par le temps passé dans les parties gauche et droite. Les souris exposées à l'urine de donneuses en fin de lactation ont moins reniflé que celles des autres échantillons, bien que des préférences pour le reniflement d'urine à laquelle elles avaient été exposées dès leur mise-bas aient été moins prononcées. L'urine n'a pas accéléré la puberté, mais les souris de l'échantillon contrôle ont révélé davantage de frottis vaginaux caractéristiques du diœstrus et moins de frottis vaginaux avec une prédominance de cellules épithéliales.

\section{References}

BINGEL A. S., SCHWARTZ N. B., 1969a. Pituitary LH content and reproductive tract changes during the mouse oestrous cycle. J. Reprod. Fert., 19, 215-222.

BINGEL A. S., SCHWARTZ N. B., 1969b. Timing of LH release and ovulation in the cyclic mouse. J. Reprod. Fert., 19, 223-229.

BRUCE H. M., 1959. An exteroceptive block to pregnancy in the mouse. Nature, Lond., 184, 105.

BRUCE H. M., 1970. Pheromones. Brit. Med. Bull., 26, 10-13.

COLBY D. R., VANDENBERGH J. G., 1974. Regulatory effects of urinary pheromones on puberty in the mouse. Biol. Reprod., 11, 268-279.

COWLEY J. J., SMALE S., 1986. Long term effects on activity in female mice following exposure to urine from lactating mothers. Physiol. Behav. (in Press).

COWLEY J. J., WILLIAMSON A. J., BERRYMAN J. C., 1969. Movement, restriction, food intake a.nd behaviour of the mouse. Excerpta med. int. Congr. Ser., Amsterdam, 213, 244-249.

COWLEY J. J., WISE D. R., 1970. Pheromones, growth and behaviour, 144-170. In Chemical influences on behaviour, Ciba Fdn. Study Grp., Churchill, London.

COWLEY J. J., WISE D. R., 1972. Some effects of mouse urine on neonatal growth and reproduction. Anim. Behav., 20, 499-506.

CSERMELY D., 1981. Paternal influences on locomotor activity of the new born mouse. Monitore Zool. ital. (N. S.), 15, 307-308.

DLUZEN D. E., RAMIREZ V. D., CARTER C. S., GETZ L. L., 1981. Male vole urine changes Luteinizing Hormone Releasing Hormone and Norepinephrine in female olfactory bulb. Science, 212, 573-575.

DLUZEN D. E., RAMIREZ V. D., 1983. Localized and discrete changes in neuropeptide (LHRH and TRH) and neurotransmitter (NE and DA) concentrations within the olfactory bulbs of male mice as a function of social interaction. Horm. Behav. 17, 139-145.

DRICKAMER L. C., 1977. Delay of sexual maturation in female house mice by exposure to grouped females or urine from grouped females. J. Reprod. Fert., 51, 77-81.

DRICKAMER L. C., HOOVER J. E., 1979. Effects of urine from pregnant and lactating female house mice on sexual maturation of juvenile females. Dev. Psychobiol., 12, 545-551.

DRICKAMER L. C., 1984. Sexual variation in acceleration and delay of sexual maturation in female mice by urinary chemosignals. J. Reprod. Fert., 72, 55-58.

FOOTE T. P., 1974. The activity of mice during the oestrous cycle, pregnancy and lactation. PhD Thesis, The Queen's University, Belfast.

FULLERTON C., COWLEY J. J., 1971. The differential effect of the presence of adult male and female mice on the growth and development of the young. J. genet. Psychol., 119, 89-98.

HARVEY F. E., COWLEY J. J., 1984. Effects of external chemical environment on the developing olfactory bulbs of the Mouse (Mus musculus). Brain Res. Bull., 13, 541-547.

KEVERNE E. B., DE LA RIVA C., 1982. Pheromones in mice : reciprocal interaction between the nose and brain. Nature, 296, 148-150.

MCCLINTOCK M. K., 1983. Modulation of the oestrous cycle by pheromones from pregnant and lactating rats. Biol. Reprod., 28, 823-829. 
MISSLIN R., ROPARTZ Ph., 1981. Olfactory regulation of responsiveness to novelty in mice. Behav. neural. Biol., 33, 230-236.

VANDENBERGH J. G., 1967 . Effect of the presence of a male on the sexual maturation of female mice. Endocrinology, 81, 345-349.

VANDENBERGH J. G., 1969. Male odour accelerates female maturation in mice. Endocrinology, 84, 658-660. 